\title{
Compassionate Drug Use - Time Arising for a New Law in Bulgaria in the Era of COVID-19
}

\author{
Nigyar Dzhafer ${ }^{1}$, Jannis V. Papathanasiou ${ }^{2}$ \\ ${ }^{1}$ Department of Health Policy and Management, Faculty of Public Health, Medical University of Sofia, Sofia, Bulgaria \\ ${ }^{2}$ Faculty of Dental Medicine, Medical University of Plovdiv, Plovdiv; Faculty of Public Health, Medical University of Sofia, Sofia, Bulgaria
}

Corresponding author: Jannis V. Papathanasiou, Faculty of Dental Medicine, Medical University of Plovdiv, 15A Vassil Aprilov Blvd., 4002 Plovdiv, Bulgaria; E-mail: giannipap@yahoo.co.uk; Tel.: +359 889101178

Received: 28 Apr 2020 Accepted: 1 June 2020 Published: 30 Sep 2020

Citation: Dzhafer N, Papathanasiou JV. Compassionate drug use - time arising for a new law in Bulgaria in the era of COVID-19. Folia Med (Plovdiv) 2020;62(3):592-6. doi: 10.3897/folmed.62.e53742.

\begin{abstract}
Introduction: Despite clinical trials, there are still no approved specific therapies or any vaccine against COVID-19. The only option available is using investigational drugs for compassionate use. The update of the existing regulation regarding compassionate use is to ensure the effective and sustainable development of health policies and technologies over the COVID-19 pandemic and beyond.
\end{abstract}

Aim: The present short communication aimed to highlight the need for early and expanded access to investigational drugs for compassionate use as well as a call for an update of the existing regulation in Bulgaria concerning compassionate use in the era of COVID-19.

Materials and Methods: In EU and Bulgaria as well, the legal framework for compassionate use was introduced by Article 83 (1) of Regulation (EC) No 726/2004 of the European Parliament and of the Council; in principle, Regulations of the European Parliament and of the Council are mandatory for all Member States. Remdesivir appears to have a favorable clinical and safety profile, as reported in a case involving patients with severe COVID-19 through a compassionate use programme.

Results: The overall probability of clinical improvement observed in 36 of 53 COVID-19 patients received intravenous remdesivir as part of a compassionate use programme was $68 \%$ (95\% CI $40 \%$ to $80 \%$ ). Thirty two patients (60\%) demonstrated at least one adverse event, twelve 12 patients (23\%) experienced serious adverse events and seven patients (13\%) died.

Conclusion: The global pandemic mandates Bulgarian Drug Agency for a reasonable update of the existing national regulation concerning compassionate use and off-label therapies. In the era of COVID-19, it is important for Bulgarian patients to have early and expanded access to investigational drugs for compassionate use.

\section{Keywords}

COVID-19, compassionate use, off-label, regulation, remdesivir

\section{INTRODUCTION}

Nowadays, the health care systems over the world, including the Bulgarian face unprecedented stress trying to take control over the pandemic of COVID-19. According to Johns Hopkins University (JHU) of Medicine statis- tics, SARS-CoV-2 virus-induced coronavirus disease 2019 (COVID-19) has spread today (May 12, 2020) to 212 countries, having infected 4238703 people globally leading to 290296 deaths (7.00\% case-fatality ratio). The statistics for the same date in Bulgaria indicate 2023 infections and 95 deaths ( $4.70 \%$ case-fatality ratio), accounting for $0.047 \%$ of global infections and $0.032 \%$ of total deaths. ${ }^{1}$ 


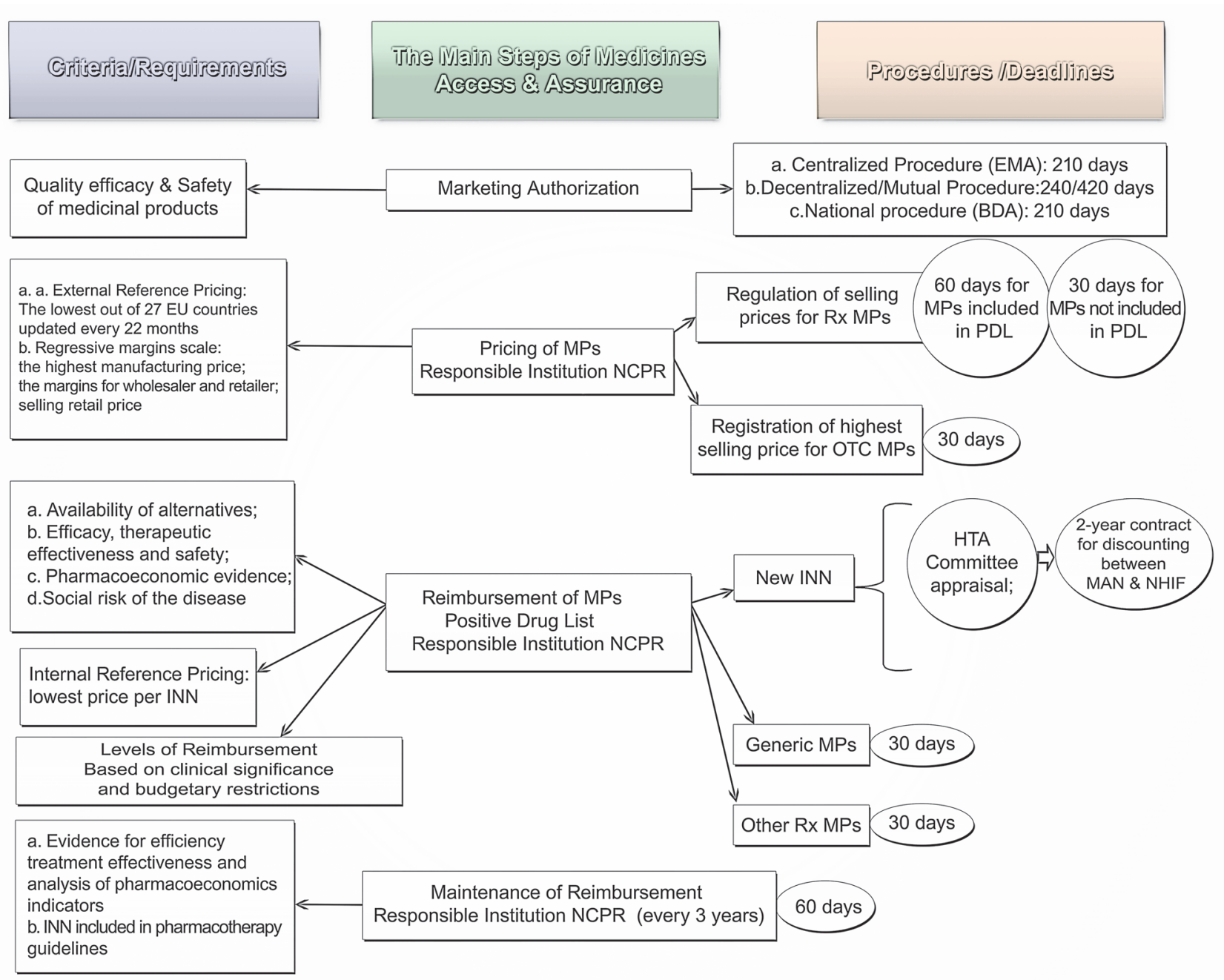

Figure 1. Health Technology Assessment, Pricing, and Reimbursement Framework of Medicines in Bulgaria.

Bulgarian Drug Agency (BDA), European Medicines Agency (EMA), National Health Insurance Fund (NHIF), International Nonproprietary Name (INN), Health Technology Assessment (HTA), Marketing Authorization Holder (MAH), National Council on Prices and Reimbursement (NCPR), Medicinal Products (MPs), Positive Drug List (PDL), Over the Counter (OTC).

As COVID-19 was first reported in Bulgaria (8-th March 2020), the Government rapidly introduced restrictive measures including general lockdown and social distancing. ${ }^{2}$ Despite the control measures taken, the Bulgarian health policymakers are challenging to implement effective reforms adapted to the new social and economic era of COVID-19.

The Bulgarian health care system is highly centralized, with a single payer to administer social health insurance, as well as limited supply of workforce and bed capacity of intensive care units (ICU). ${ }^{3}$ Health Technology Assessment (HTA) included pricing and reimbursement framework for new medicines was recently introduced (Fig. 1). ${ }^{4}$ However, the challenge of COVID-19 mandates a comprehensive update of the existing Law for medicines, with a particular focus on the national regulation compassionate use (CU) of drugs.

At least 25 drugs are under investigation for $\mathrm{CU}$ in $\mathrm{CO}$ -
VID-19 patients, with 10 in active clinical trials. Despite these clinical trials, there are still no specific therapies or any vaccine against COVID-19, approved by the Food and Drug Administration (FDA), the European Medicines Agency (EMA) ${ }^{5}$, as well as the Bulgarian Drug Agency (BDA). The available options are using investigational drugs (antiretrovirals, anti-inflammatory compounds and antiparasitic agents) on a compassionate use basis. ${ }^{6}$ In the era of the COVID-19 pandemic, it is vital for Bulgarian patients to have early and expanded access to investigational drugs for compassionate therapies.

\section{AIM}

The present short communication aimed to highlight the need for early and expanded access to investigational drugs for $\mathrm{CU}$ as well as a call for an update of the existing regu- 
lation in Bulgaria concerning CU in the era of COVID-19.

\section{MATERIALS AND METHODS}

According to the EMA "CU a treatment option that allows the use of an unauthorized medicinal product which is under development". In EU and Bulgaria as well, the legal framework for CU was introduced by Article 83 (1) of Regulation (EC) No 726/2004 of the European Parliament and of the Council; in principle, Regulations of the European Parliament and of the Council are mandatory for all Member States. Additionally a more detailed guidance on implementation of Art. 83 (1), was provided of the Committee for Medicinal Products for Human Use (CHMP) of the EMA which issued Guideline on Compassionate Use of Medicinal Products. ${ }^{7}$ In fact, many EU Member States have already introduced national regulations and procedures for the CU of drugs. ${ }^{8,9}$

As the SARS-CoV-2 continues to spread rapidly across the world, the request for CU has risen exponentially. On 25th and 26th of March 2020, four EU countries (Estonia, Greece, Netherlands and Romania) requested an opinion on the $\mathrm{CU}$ for remdesivir from the EMA Committee for Medicinal Products for Human Use (CHMP), in accordance with Article 83(3) of Regulation (EC) No 726/2004. The legal basis for this application refers to: Article 83(3) of Regulation (EC) No 726/2004. The CHMP supports this position and considers that the CU programs should be used for patients who do not participate in a clinical trial. ${ }^{10}$

While the epidemiological data provided for the critically ill COVID-19 patients in Bulgaria ${ }^{1}$ is not comparable with the ones observed in USA, Russia, UK, Italy and Spain, crucial to ensure the early and expanded access of Bulgarian patients to new medicines through CU programs. Remdesivir is an active adenosine analogue that enters and accumulates in cells, inhibiting viral RdRp4 and stopping viral replication. ${ }^{11}$ Coronaviruses (e.g., SARS/ MERS-CoV5, SARS-CoV-2) have a "proofreading" enzyme (exoribonuclease) that corrects errors in the RNA sequence, potentially limiting the effects of analogues ${ }^{12,13}$, but remdesivir is able to evade this proofreading. ${ }^{14,15}$ In the laboratory, viral mutation can lead to resistance to remdesivir, but the mutantviruses are less infective. Remdesivir appears to have a favorable clinical safety profile, as reported in a case involving patients with severe COVID-19 through a CU program. ${ }^{14}$

\section{RESULTS}

The first patient to present with COVID-19 in the U.S. was treated with intravenous remdesivir under the CU clause after developing pneumonia. ${ }^{16}$ This 35 -year-old male had been infected during travel to Wuhan and returned to the U.S. in January 2020 where he was hospitalized for more than 12 days. He was treated with intravenous remdesi- vir on the seventh day, and his condition was reportedly improving on the eighth day. No adverse events related to remdesivir use were noted.

During the time when this short communication was reviewed, in an observational study conducted in over 20 hospitals on three continents clinical improvement has been observed in 36 of 53 COVID-19 patients treated with remdesivir. ${ }^{17}$ Patients received at least one dose of a 10 day course of intravenous remdesivir as part of a CU programme organized by the manufacturer (Gilead Sciences, Inc.). Thirty patients were being ventilated and four treated with extracorporeal membrane oxygenation (ECMO) at the start of remdesivir treatment. After a median of 18 days, 25 patients (47\%) had been discharged and seven (13\%) had died. Mortality was 5\% among patients who were not ventilated. The overall probability of improvement by 18 days was $68 \%$ (95\% CI $40 \%$ to $80 \%$ ). Thirty two patients (60\%) demonstrated at least one adverse event and twelve 12 patients $(23 \%)$ experienced serious adverse events.

Decreased need for oxygen support, was observed in the majority of patients with COVID-19 in this report, however the lack of comparison group limit the interpretation of the clinical outcomes.

\section{DISCUSSION}

Despite the growing requests from clinicians globally for CU, no requests for investigational antiviral drugs (e.g. remdesivir) for COVID-19 were submitted from the Bulgarian clinicians and hospitals. For example, remdesivir is not approved by the FDA, EMA and BDA, and may only be obtained through participation in registered clinical trials or via $\mathrm{CU}$ request to the manufacturer (Gilead Sciences, Inc.).

Unlike to many EU countries, who have well-defined national regulations for $\mathrm{CU}^{8}$ of drugs, there are no articles which guarantee patient expanded access to investigational drugs for CU in the existing Law for medicines and pharmacies in Bulgaria. According the existing regulation ${ }^{18}$ an investigational drug must be included in HTA and pricing evaluation procedures which are time-consuming (e.g. 6-8 months), and practically the one year authorization for CU usually expires during the carry out of the above mentioned procedures. ${ }^{19}$ After the expiration and depending on sufficient data for efficacy and safety, an investigational drug will take authorization for distribution in pharmaceutical market in Bulgaria for 5 years, as well the HTA and pricing procedure will be initiated.

The mechanisms for delivery of unauthorized drugs in the Bulgarian pharmaceutical market, are similar to those, functioning in the UK. The clinicians are enabling to order unauthorized drugs through hospital pharmacies, however the pricing process of these drugs is unclear. There is a potential risk for the expenses to be borne by the patient; a fact that raises significant social and ethical issues, related to the patients' clinical condition. There is a need for articles' update, which will facilitate the patients early access 
to investigational medicines, intended for CU during the one-year period of this authorization.

These weak points in the existing national regulation make the access to investigational drugs for Bulgarian patients practically impossible, and exclude many patient groups who are unable to fulfill the rigorous eligibility criteria of clinical trials. This may restrict critically ill patients, even those with COVID-19, from hopeful treatments and drugs at an earlier stage, post phase II.

It is well known that the pharmaceutical companies face many challenges with the existing national regulation in Bulgaria. The regulation update will help the pharmaceutical industry to provide a quick and efficient response to patients' increased demand for investigational drugs via CU programs and will contribute to a smoother transition of these drugs to the Bulgarian pharmaceutical market. ${ }^{4}$ Additionally, BDA as well as the pharmaceutical companies should take steps towards implementing CU and considering the benefits and importance of early access of patients to investigational drugs.

On the other hand, this update will guarantee a smoother transition of an investigational drug to the pharmaceutical market in Bulgaria. In the new regulation, the specific phases involved in the CU and a clear pricing and reimbursement framework need to be determined.

The COVID-19 pandemic is a challenge for the Bulgarian health policy makers, BDA as well as the pharmaceutical companies. It will test their ability to develop new strategies and adequate pharmaceutical policies and regulations in order to respond to the challenges that the Bulgarian health care system currently faces. ${ }^{11,20}$

We suggest that the regulation update in the era of COVID-19 will potentially initiate a dialogue among stakeholders for reforms in the legal framework regarding CU, not only in Bulgaria but also in other EU Member States in order to correspond to higher demand of patients for investigational drugs and new promising therapies.

\section{CONCLUSION}

The global pandemic mandates Bulgarian Drug Agency for a reasonable update of the existing national regulation concerning compassionate use and off-label therapies. In the era of COVID-19, it is important for Bulgarian patients to have early and expanded access to investigational drugs for compassionate use.

\section{REFERENCES}

1. Johns Hopkins University \& Medicine. Coronavirus Resoursce Center. (https://coronavirus.jhu.edu/map.html) Accessed 12th May, 2020.

2. http://www.mh.government.bg/media/filer_public/2020/03/13/rd01-124-vuvejdane-protiepidemichni-merki.pdf Accessed 27th April, 2020.

3. Dimova A, Rohova M, Koeva S, et al. Bulgaria: Health System Review.
Health Syst Transit 2018; 20:1-230.

4. Vassileva M, Kamusheva M, Manova M, et al. Historical overview of regulatory framework development on pricing and reimbursement of medicines in Bulgaria. Expert Rev Pharmacoecon Outcomes Res 2019; 19(6):733-742.

5. European Medicines Agency. Summary on compassionate use: Remdesivir Gilead. (https://www.ema.europa.eu/en/documents/other/ summary-compassionate-use-remdesivir-gilead_en.pdf) Accessed 20th April, 2020.

6. Kalil AC. Treating COVID-19-Off-Label Drug Use, Compassionate Use, and Randomized Clinical Trials During Pandemics. JAMA 2020. doi: 10.1001/jama.2020.4742.

7. European Medicines Agency (Committee for Medicinal Products for Human Use). Guideline on compassionate use of medicinal products, pursuant to article 83 of regulation (EC) no 726/2004 Available at http://www.ema.europa.eu/docs/en_GB/ document_library/Regulatory_and_procedural_guideline/2009/10/WC500004075.pdf; 2007, Accessed 10th May, 2020.

8. Balasubramanian G, Morampudi S, Chhabra P, et al. An overview of compassionate use programs in the European Union member states. Intractable Rare Dis Res 2016; 5:244-54.

9. Borysowski J, Górski A.Compassionate use of unauthorized drugs: Legal regulations and ethical challenges. Eur J Intern Med 2019; 65:12-16. doi: 10.1016/j.ejim.2019.04.008.

10. https://www.ema.europa.eu/en/documents/other/summarycompassionate- use-remdesivir-gilead_en.pdf; Accessed May 10. 2020.

11. Ferner RE, Aronson JK. Remdesivir in covid-19. BMJ. 2020 Apr 22;369:m1610. doi: 10.1136/bmj.m1610.

12. Agostini ML, Andres EL, Sims AC, etal . Coronavirus susceptibility to the antiviral remdesivir (GS-5734) is mediated by the viral polymerase and the proofreading exoribonuclease. mBio 2018;9:e0022118. 10.1128/mBio.00221-18 29511076.

13. Pruijssers AJ, Denison MR. Nucleoside analogues for the treatment of coronavirus infections. Curr Opin Virol 2019; 35:57-62. doi: 10.1016/j.coviro.2019.04.002.

14. Gordon CJ, Tchesnokov EP, Woolner E, et al.Remdesivir is a directacting antiviral that inhibits RNA-dependent RNA polymerase from severe acute respiratory syndrome coronavirus 2 with high potency. J Biol Chem 2020; 295(20):6785-6797. doi: 10.1074/jbc.RA120.013679.

15. Warren TK, Jordan R, Lo MK, et al. Therapeutic efficacy of the small molecule GS-5734 against Ebola virus in rhesus monkeys. Nature 2016;531(7594):381-5. doi: 10.1038/nature17180.

16. Holshue ML, DeBolt C, Lindquist S, et al. First case of 2019 novel coronavirus in the United States. N Engl J Med 2020; 382: 929-36.

17. Grein J, Ohmagari N, Shin D, et al. Compassionate use of remdesivir for patients with severe Covid-19. N Engl J Med 2020. doi: 10.1056/ NEJMoa2007016.

18. Vella Bonanno P, Bucsics A, Simoens S, et al. Proposal for a regulation on health technology assessment in Europe - opinions of policy makers, payers and academics from the field of HTA. Expert Rev Pharmacoecon Outcomes Res 2019; 19(3):251-261. doi: 10.1080/14737167.2019.1575730.

19. Godman B, Bucsics A, Vella Bonanno P, et al. Barriers for Access to New Medicines: Searching for the Balance Between Rising Costs and Limited Budgets. Front Public Health 2018; 6:328. doi: 10.3389/ fpubh.2018.00328.

20. Singer DR. Health policy and technology challenges in responding to the COVID-19 pandemic. Health Policy Technol 2020. doi: 10.1016/j. hlpt.2020.04.011. 


\title{
Сострадательное применение лекарственных средств - время для нового закона в Болгарии в эпоху COVID-19
}

\author{
Нигяр Джафер ${ }^{1}$, Янис В. Паптанасиу ${ }^{2}$ \\ ${ }^{1}$ Кафедра „Политика и менеджмент здравоохранения“, Факультет общественного здравоохраненя, Медицинский университет - София, \\ София, Болгария \\ ${ }^{2}$ Факультет дентальной медицины, Медицинский университет - Пловдив, Пловдив, Болгария; Факультет общественного здравоохраненя, \\ Медицинский университет - София, София, Болгария
}

Адрес для корреспонденции: Янис В. Паптанасиу, Факультет дентальной медицины, Медицинский университет - Пловдив, бул. „Васил Априлов“ № 15A, 4002 Пловдив, Болгария; E-mail: giannipap@yahoo.co.uk; Тел: +359 889101178

Дата получения: 28 апреля 2020 Дата приемки: 1 июня $2020 \bullet$ Дата публикации: 30 сентября 2020

Образец цитирования: Dzhafer N, Papathanasiou JV. Compassionate drug use - time arising for a new law in Bulgaria in the era of COVID-19. Folia Med (Plovdiv) 2020;62(3):592-6. doi: 10.3897/folmed.62.e53742.

\section{Резюме}

Введение: Несмотря на несколько клинических исследований, до сих пор нет специальных методов лечения или вакцин против COVID-19. Единственный вариант - применение лекарственных средств в процессе исследования сострадательного применения. Актуалзация существующего национального законодательства в отношении сострадательного применения лекарственных средств имеет решающее значение для обеспечения устойчивого развития политики и технологий здравоохранения во время и после пандемии COVID-19.

Цель: Настоящее короткое коммюнике направлено на то, чтобы подчеркнуть необходимость раннего и расширенного доступа к лекарственным средствам в процессе исследования сострадательного применения для болгарских пациентов, а также актуализировать существуюеее национальное законодательство в отношении сострадательного применения в эпоху COVID-19.

Материалы и методы: В ЕС и в Болгарии законодательная база была введена статьей 83 (1) Регламента № 726/2004 Европейского парламента и Совета; в принципе, положения Европейского парламента и Совета являются обязательными для всех государств-членов. По-видимому, ремдесивир имеет благоприятный профиль клинической безопасности в отношении пациентов с тяжёлой формой COVID-19, включенных в программу сострадательного применения.

Результаты: Общая вероятность клинического улучшения, наблюдаемого у 36 из 53 пациентов с COVID-19, получавших внутривенное введение ремдесивира в рамках программы сострадательного применения лекарственных средств, составила 68\% (95\% СІ от 40\% до 80\%). Тридцать два пациента (60\%) испытали по крайней мере один побочный эффект, 12 пациентов (23\%) испытали серьёзные побочные эффекты, а семь пациентов (13\%) умерли.

Заключение: Глобальная пандемия обязывает Болгарское агентство по лекарственным средствам осуществить разумную актуализацию действующего национального законодательства, касающегося сострадательного применения лекарственных средств и нелицензированных методов лечения („офф-лейбл“). В эпоху COVID-19 важно, чтобы болгарские пациенты имели быстрый и расширенный доступ к экспериментальным лекарствам для сострадательного применения.

\section{Ключевые слова}

COVID-19, сострадательное применение, офф-лейбл, законодательство, ремдесивир 